\title{
Heterogeneity in Hormone Responses and Patterns of Collagen Synthesis in Cloned Dermal Fibroblasts
}

Steven R. Goldring, Mary L. Stephenson, Elaine Downie, Stephen M. Krane, and Joseph H. Korn

Department of Medicine, Harvard Medical School, Boston, Massachusetts 02115; Medical Services (Arthritis Unit), New England

Deaconess Hospital, Boston, Massachusetts 02215; Massachusetts General Hospital, Boston, Massachusetts 02114; and the

Division of Rheumatic Diseases, Veterans Administration Medical Center, University of Connecticut

School of Medicine, Newington, Connecticut 06111

\begin{abstract}
Fibroblasts cultured from normal human dermis are heterogeneous with respect to growth kinetics, synthetic function, and morphologic features. There are many examples of clonal heterogeneity in apparently homogeneous connective tissue cell populations, and it has been suggested that selection of cell populations with particular phenotypic features is the basis for the development of pathologic connective tissue changes in inflammatory disorders. In these studies we report characterization of the pattern of matrix biosynthesis and responses to hormones in cells cloned from normal human dermis. The results indicate that cloned dermal fibroblasts are heterogeneous with respect to synthesis of collagens as well as their responses to prostaglandin $E_{2}$ and parathyroid hormone. Selective expansion of clonal populations with unique patterns of matrix synthesis and cell surface receptors could provide the basis for abnormal connective tissue remodeling in certain pathologic states. (J. Clin. Invest. 1990. 85:798-803.) hormone • collagen - connective tissue cell
\end{abstract}

\section{Introduction}

Examination of the growth kinetics and morphologic features of fibroblasts cultured from neonatal human skin have demonstrated that these cells are genetically and phenotypically diverse (1-7). Examples of clonal heterogeneity in apparently homogeneous connective tissue cell populations have been reported, and it has been suggested that temporal selection of individual cell populations could be involved in cellular remodeling of connective tissues under physiologic conditions (1-9). Similar mechanisms could also be involved in pathologic states in which monoclonal or oligoclonal cell populations possessing unfavorable or inappropriate phenotypic features could be selected (10-15).

The initial goal of these studies was to determine the degree of phenotypic diversity in the pattern of matrix biosynthesis among normal skin fibroblasts. We observed significant differences in the pattern of collagen synthesis in substrains cloned from normal neonatal foreskin. These findings can be

Address correspondence to Dr. Steven R. Goldring, Massachusetts General Hospital-East, 149 The Navy Yard, 13th Street, Charlestown, MA 02129.

Received for publication 25 July 1989 and in revised form 9 November 1989.

J. Clin. Invest.

(C) The American Society for Clinical Investigation, Inc.

0021-9738/90/03/0798/06 \$2.00

Volume 85, March 1990, 798-803 accounted for in part, by differential regulation of collagen synthesis at the transcriptional level.

The second goal of our studies was to determine whether heterogeneity also exists in responses involving cell surface receptors for hormones known to affect connective tissue remodeling. We therefore examined the pattern and magnitude of 3'-5'-cAMP responses to $\mathrm{PGE}_{2}$ and PTH. Marked heterogeneity in the cAMP responses to these hormones was also observed, although there was no correlation between the rate of collagen synthesis and the magnitude or pattern of hormone responses. Selective expansion of clonal populations in vivo could thus give rise to tissues with unique patterns of matrix synthesis and altered responses to hormonal regulation.

\section{Methods}

Processing of tissue. Samples of neonatal foreskin obtained from routine circumcision were digested with clostridial collagenase. Substrains were isolated from primary cultures by limiting dilution cloning (1-4). Once confluent, cultures of these clones were maintained in basal Eagle's medium supplemented with FCS and carried through multiple passages after trypsinization.

Hormone responses. Cells were passaged into 24-well trays (Costar, Cambridge, MA) at $\sim 5 \times 10^{4}$ cells/well. cAMP responses were assessed by incubating cells for $20 \mathrm{~min}$ at $37^{\circ} \mathrm{C}$ in buffer containing 1 mM 3-isobutyl-1-methylxanthine (IBMX) ${ }^{1}$ (Aldrich Chemical Co., Milwaukee, WI) in the absence or presence of either $\mathrm{PGE}_{2}$ or PTH. cAMP content was determined by radioimmunoassay (Becton-Dickinson \& Co., Paramus, $\mathrm{NJ})(16,17)$. $\mathrm{PGE}_{2}$ was a gift of the Upjohn Co., Kalamazoo, MI. Bovine PTH ( 3,000 U/mg) extracted from TCA precipitates of bovine parathyroid glands and purified by gel filtration and ion exchange chromatography on carboxymethyl-cellulose was a gift of Dr. Henry T. Keutmann (Massachusetts General Hospital, Boston, MA)

Labeling of medium collagens. Cells were plated at $2 \times 10^{5}$ cells/ dish in $3.5-\mathrm{cm}$ dishes and $2 \mathrm{~d}$ later incubated for $24 \mathrm{~h}$ with L- $\left[5-{ }^{3} \mathrm{H}\right]-$ proline $(30 \mu \mathrm{Ci} / \mathrm{mmol})$ in the presence of $50 \mu \mathrm{g} / \mathrm{ml}$ beta-aminoproprionitrile, $50 \mu \mathrm{g} / \mathrm{ml}$ ascorbic acid, and $2 \mathrm{mM}$ glutamine in the absence of serum. We have previously found that under these conditions medium collagen accounts for $>95 \%$ of total collagen synthesized. Medium proteins which included procollagens and processed procollagen were analyzed by SDS-PAGE with or without reduction with $0.5 \%$ $\beta$-mercaptoethanol and fluorography as previously described (18). Labeled collagens were further characterized by pepsinization at $4^{\circ} \mathrm{C}$ followed by SDS-PAGE with or without delayed reduction to distinguish $\alpha 1$ (I) from $\alpha 1$ (III) collagen chains $(18,19)$.

Analysis of collagen mRNAs. Cytoplasmic RNA was extracted from cells by the method of White and Bancroft (20). After denaturation in $7.5 \%$ formaldehyde, dot hybridization was performed as described previously using cDNA probes labeled by nick translation (21, 22). The following cDNAs were used: Hf677, a 1,500-bp cDNA en-

1. Abbreviation used in this paper: IBMX, 3-isobutyl-1-methylxanthine. 
coding part of the $\alpha 1$ (I) procollagen subunit (23), and Hf1131, a 1,500-bp cDNA encoding part of the $\alpha 2$ (I) procollagen subunit (24) provided by Dr. F. Ramirez and Dr. D. J. Prockop. The cDNA for the $\alpha 1$ (III) procollagen, pHCIII-I, was provided by Dr. R. G. Crystal and Dr. M. Brantly, National Institutes of Health (NIH; 25). Specific activities of the labeled probes were $\sim 2.16,1.77$, and $1.45 \times 10^{8} \mathrm{cpm} / \mu \mathrm{g}$ DNA for the $\alpha 1$ (I), $\alpha 2(\mathrm{I})$, and $\alpha 1$ (III) procollagen cDNAs, respectively

For Northern hybridization, total RNA was extracted using the guanidine-thiocyanate procedure (21). Total RNA (5 $\mu \mathrm{g})$ was denatured by treatment with formaldehyde-formamide and electrophoresed on $0.8 \%$ agarose gels containing $0.22 \mathrm{M}$ formaldehyde. The RNA was transferred to nitrocellulose paper and hybridized using the cDNA probes described above (21). The relative intensity of the $28 \mathrm{~S}$ and $18 \mathrm{~S}$ ribosomal RNA, compared with background as an index of RNA breakdown, was assessed using ethidium bromide and visualized under ultraviolet light. Nick translation, prehybridization, and hybridization with the procollagen cDNAs were performed as described (21).

\section{Results}

We have previously shown that cells cultured from human dermis increase cAMP content in response to PTH or $\mathrm{PGE}_{2}$ $(26,27)$. To examine the pattern of hormone-induced cAMP responses in dermal fibroblasts, 24 cell substrains cloned by limiting dilution from three neonatal foreskin samples were incubated with maximal stimulatory concentrations of PTH or $\mathrm{PGE}_{2}$. The three parent cultures of fibroblasts were responsive to both hormones. All substrains prepared from the parent cultures from two of the samples (D.W. and J.R.) increased cAMP content when tested with PTH or $\mathrm{PGE}_{2}$, although there were marked differences in the magnitude of the cAMP responses. Although cells from the third parent culture (L.T.F.) were responsive to $\mathrm{PTH}$, none of the substrains increased cAMP levels in response to PTH (Table I). These substrains were, however, responsive to $\mathrm{PGE}_{2}$.

Fig. 1 shows the relationship between PTH- and PGE-induced cAMP responses in clones from sample D.W. Although there was a correlation of the PTH and $\mathrm{PGE}_{2}$ responses in substrains from parent culture D.W. $(r=0.77)$, there was no correlation in the responses to the two hormones in the substrains from parent culture J.R. (not shown). Patterns of responsiveness to $\mathrm{PTH}$ and $\mathrm{PGE}_{2}$ remained stable after passage; in general, substrains exhibiting the greatest hormone-induced increases in CAMP levels continued to show enhanced sensitivity to hormonai stimulation.

Table I. Comparison of PTH-induced cAMP Response in a Parent Dermal Cell Culture and Two Representative Substrains

\begin{tabular}{lcccc}
\hline & \multicolumn{3}{c}{ cAMP } \\
\cline { 2 - 4 } & Parent & & \multicolumn{2}{c}{ Substrains } \\
\cline { 2 - 4 } & L.T.F. & & $\mathrm{C}$ & $\mathrm{K}$ \\
\cline { 3 - 5 } & & pmol/well & \\
& & & $0.55 \pm 0.13$ & $0.45 \pm 0.06$ \\
Buffer & $1.84 \pm 0.45$ & & $0.52 \pm 0.06$ & $0.57 \pm 0.04$ \\
PTH & $7.60 \pm 1.82$ & & $47.7 \pm 4.03$ & $6.40 \pm 0.93$
\end{tabular}

Cells were incubated for $20 \mathrm{~min}$ at $37^{\circ} \mathrm{C}$ with buffer containing (1 mM) IBMX with or without PTH $\left(10^{-7} \mathrm{M}\right)$ or $\pm \mathrm{PGE}_{2}\left(2.5 \times 10^{-6}\right.$ $M)$. Values represent mean \pm SEM.

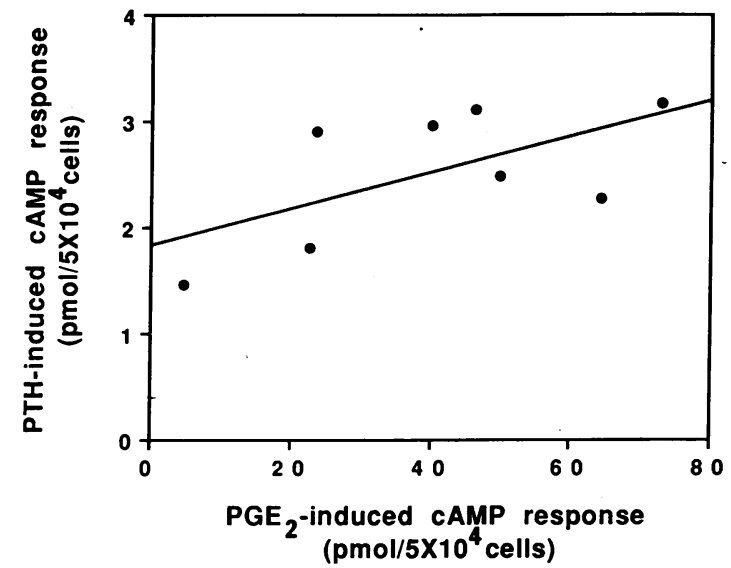

Figure 1. Comparison of the PTH- and $\mathrm{PGE}_{2}$-induced cAMP responses to maximal stimulatory concentrations of hormone in substrains from parent dermal culture D.W. Cells in 24-well trays were incubated $20 \mathrm{~min}$ at $37^{\circ}$ in the presence of $1 \mathrm{mM}$ IBMX $\pm \mathrm{PTH}\left(10^{-7}\right.$ M) or $\mathrm{PGE}_{2}\left(2.5 \times 10^{-6} \mathrm{M}\right)$. Points represent means of three wells for each hormone.

We have previously described an inverse relationship between endogenous $\mathrm{PGE}_{2}$ production and the magnitude of the $\mathrm{PGE}_{2}$-induced cAMP response in different human connective tissue cell cultures (28-30). As shown in Fig. 2, there was no correlation between basal $\mathrm{PGE}_{2}$ levels and the cAMP response to this ligand in the D.W. substrains.

To further investigate the functional heterogeneity of the dermal cells, substrains from the three separate parent cultures were examined for their capacity to synthesize collagen. All substrains produced types I and III collagen (analyzed after pepsinization and resolution of the labeled medium proteins by SDS-PAGE and fluorography), although there was variability in the amount and relative abundance of the individual collagen types. To quantitate the relative capacity of substrains to produce individual procollagens, cells were incubated with $\left[{ }^{3} \mathrm{H}\right]$ proline, and after separation of the pepsin-resistant me-

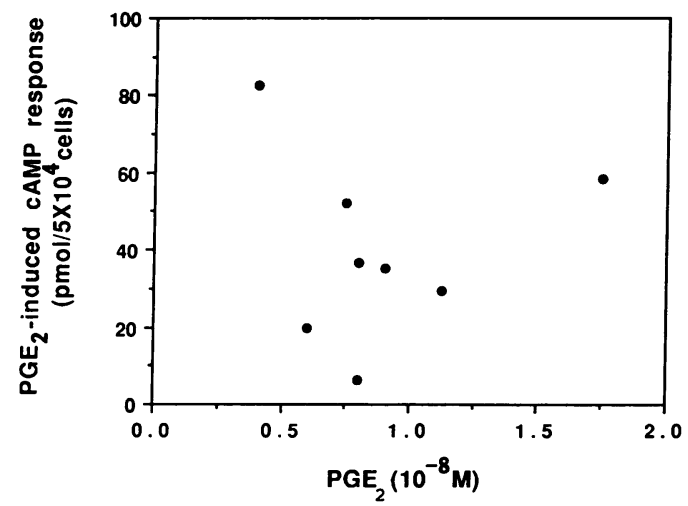

Figure 2. Comparison of the $\mathrm{PGE}_{2}$-induced cAMP response and basal $\mathrm{PGE}_{2}$ production in substrains cloned from one dermal sample. Cells in 24-well trays were incubated $20 \mathrm{~min}$ at $37^{\circ} \mathrm{C}$ in the presence or absence of a maximal stimulatory concentration of $\mathrm{PGE}_{2}$ $\left(2.5 \times 10^{-6} \mathrm{M}\right) . \mathrm{PGE}_{2}$ levels were measured after $72 \mathrm{~h}$ incubation of substrains $\left(5 \times 10^{4}\right.$ cells $)$ in culture medium alone. Values represent means of three wells. 

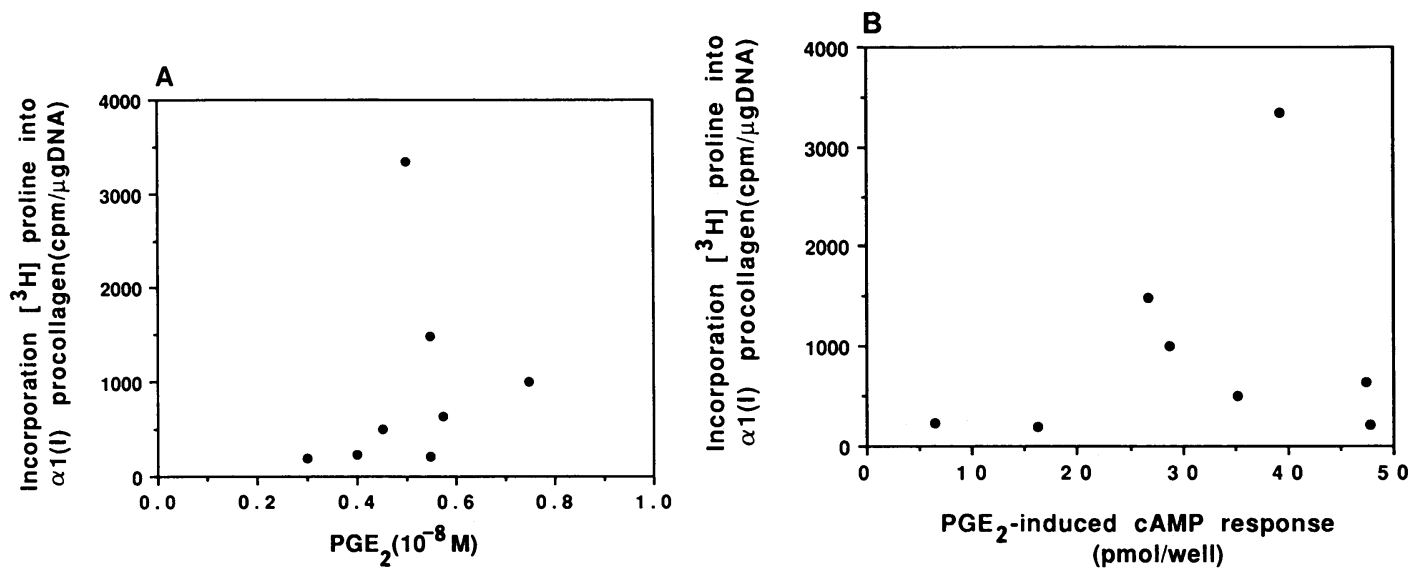

Figure 3. Capacity of dermal substains to incorporate $\left[{ }^{3} \mathrm{H}\right]$ proline into $\alpha 1$ (I) procollagen; comparison with basal $\mathrm{PGE}_{2}$ production and $\mathrm{PGE}_{2}$-induced cAMP response. Medium $\mathrm{PGE}_{2}$ was assayed in substrains (5 $\times 10^{4}$ cells) incubated 24 $h$ in culture medium alone. $\mathrm{PGE}_{2}$ responses were assessed by test-incubating cells $\left(5 \times 10^{4}\right.$ cells/well) for $20 \mathrm{~min}$ with or without $\mathrm{PGE}_{2}$ $\left(2.5 \times 10^{-6} \mathrm{M}\right) . A$ com-

pares $\mathrm{PGE}_{2}$ production to $\alpha 1$ (I) procollagen synthesis. Pepsin-resistent labeled medium proteins were separated by SDS-PAGE. The regions of the gel containing the $\alpha 1(\mathrm{I})$ procollagen bands were excised and counted. Counts have been normalized to DNA content in the culture dishes at the time of labeling. $\mathrm{PGE}_{2}$ production and $\alpha 1$ (I) procollagen synthesis were negatively correlated $(r=0.33)$. $B$ compares $\alpha 1$ (I) procollagen synthesis with the $\mathrm{PGE}_{2}$-induced cAMP responses, which were negatively correlated $(r=0.21)$.

dium proteins by SDS-PAGE the labeled bands were excised and counted. Fig. 3 shows incorporation of $\left[{ }^{3} \mathrm{H}\right]$ proline into $\alpha 1$ (I) procollagen in substrains cloned from a single sample of dermis. There was marked heterogeneity in the capacity of the substrains to synthesize $\alpha 1$ (I) procollagen. With passage of the cells the pattern of collagen synthesis among substrains remained stable. There was no correlation between the amounts of $\alpha 1$ (I) procollagen synthesized and the production of $\mathrm{PGE}_{2}(r$ $=0.33$ ) (Fig. $3 A$ ) or the magnitude of the $P E_{2}$-induced cAMP response $(r=0.21)$ (Fig. $3 B$ ).

To determine whether the heterogeneity in collagen synthesis among the substrains was correlated with steady-state levels of procollagen mRNA, cytoplasmic RNA was extracted and hybridized with labeled CDNAs for types I and III procollagen. Northern blot analysis of total RNA demonstrated that there was no cross-hybridization among the probes (data not shown). The levels of procollagen mRNA determined by dot hybridization as a function of the secreted labeled procollagen estimated by $\left[{ }^{3} \mathrm{H}\right]$ proline incorporation are shown in Fig. 4. Dot blots were quantitated by scanning with a soft laser densitometer and analyzed with an Apple IIe computer using a Zeineh Videophoresis II electrophoresis reporting program (Biomed Instruments Inc., Fullerton, CA) as previously reported (21). There was a correlation between the steady-state levels of $\alpha 1$ (I) procollagen mRNA and incorporation of $\left[{ }^{3} \mathrm{H}\right]-$ proline into $\alpha \mathrm{I}(\mathrm{I})$ collagen chains $(r=0.68)$. No correlation was found in the pattern of collagen synthesis and hormone responsiveness.

The levels of $\alpha 1$ (I) and $\alpha 2(\mathrm{I}) \mathrm{mRNAs}$ were quantitated in substrains from one parent culture (L.T.F.) by scanning the dot blots after hybridization with cDNA probes. The ratios of the $\alpha 1$ (I) and $\alpha 2(\mathrm{I})$ procollagen mRNAs in the substrains ranged from 1.37 to 2.46 . As shown in Fig. 5, the ratios of $\alpha 1(\mathrm{I}) / \alpha 2$ (I) mRNA were inversely correlated with the ratio of $\alpha 1(\mathrm{III}) / \alpha 1$ (I) plus $\alpha 2$ (I) (type III/type I collagen). Comparison of the levels of types I and III procollagen mRNA (Fig. 6) revealed a significant positive correlation $(r=0.86 ; P<0.001)$. The correlation was best between the levels of $\alpha 1$ (III) and $\alpha 2$ (I) procollagen $(r=0.89 ; P<0.001)$ compared with that of $\alpha 1$ (III) and $\alpha 1(\mathrm{I})(r=0.79 ; P<0.01)$.

\section{Discussion}

We have previously demonstrated that in response to products present in medium conditioned by PBMC, dermal fibroblast populations cultured from different individuals exhibit marked phenotypic diversity in proliferative responses and synthesis of $\mathrm{PGE}_{2}$ and collagenase (1-4). This conditioned medium contains many biologically active cytokines, such as IL-1 or tumor necrosis factor, that could potentially influence the functions of connective tissue cells. We speculated that the heterogeneity in proliferative responses to these ligands could provide a mechanism for immune-mediated clonal selection at sites of inflammation by favoring overgrowth of clonal cell populations with phenotypic characteristics that promote disease expression. It has been proposed that several chronic in-

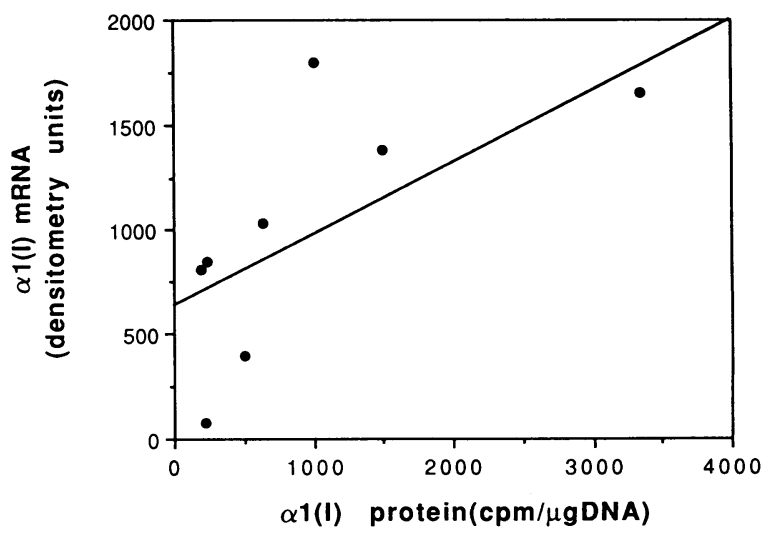

Figure 4. Comparison in dermal substrains of the $\alpha 1$ (I) procollagen mRNA levels and the amount of secreted $\alpha 1$ (I) procollagen estimated by $\left[{ }^{3} \mathrm{H}\right]$ proline incorporation. After transfer of cytoplasmic RNA to nitrocellulose and hybridization with the labeled procollagen cDNAs the autoradiographs were quantitated by densitometric scanning. Incorporation of $\left[{ }^{3} \mathrm{H}\right]$ proline into $\alpha 1$ (I) procollagen was determined by counting excised bands from SDS-PAGE gels after separation of labeled medium proteins as described in Fig. 3. Each point represents the value for a single substrain. 


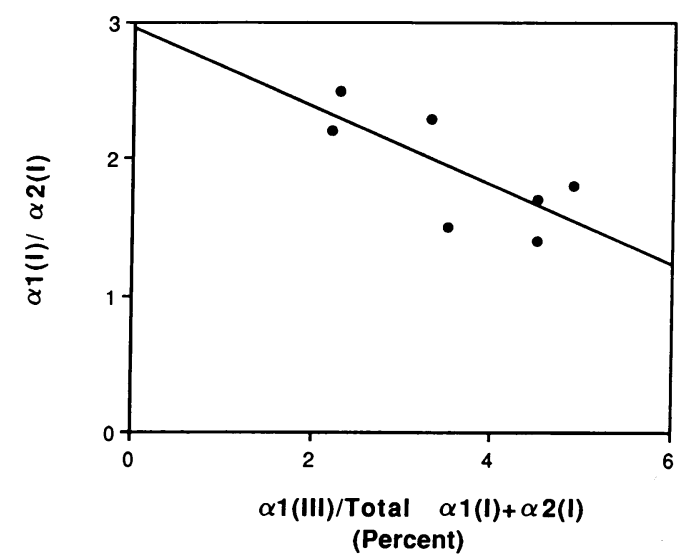

Figure 5. Comparison in dermal substrains of the ratio of $\alpha 1(\mathrm{I}) / \alpha 2(\mathrm{I})$ procollagen mRNA with the ratio of type III/type I procollagen mRNA. After extraction cytoplasmic RNA was transferred to nitrocellulose and hybridized with ${ }^{32} \mathrm{P}$-labeled $\alpha 1(\mathrm{I}), \alpha 2(\mathrm{I})$, or $\alpha 1$ (III) procollagen probes. RNA was quantitated by densitometric scanning of the autoradiographs. Each point represents the values for a single substrain.

flammatory conditions associated with increased connective tissue deposition such as hepatic cirrhosis, interstitial pneumonitis, nephritis, and scleroderma $(7,31-33)$ could be explained by selection in vivo of dominant clones of cells that proliferate and produce relatively large amounts of matrix.

In these studies we further evaluated dermal fibroblast populations by measuring the production of extracellular matrix macromolecules by substrains derived from parent cultures. Marked differences in the pattern and amounts of collagen synthesis were demonstrated. Furthermore, the differences in the amounts and types of secreted procollagens estimated by $\left[{ }^{3} \mathrm{H}\right]$ proline incorporation correlated with the steady-state levels of the corresponding procollagen mRNAs. Although these results are consistent with differential regulation of collagen synthesis at a transcriptional level, they could also be accounted for by differences in mRNA stability. Direct mea-

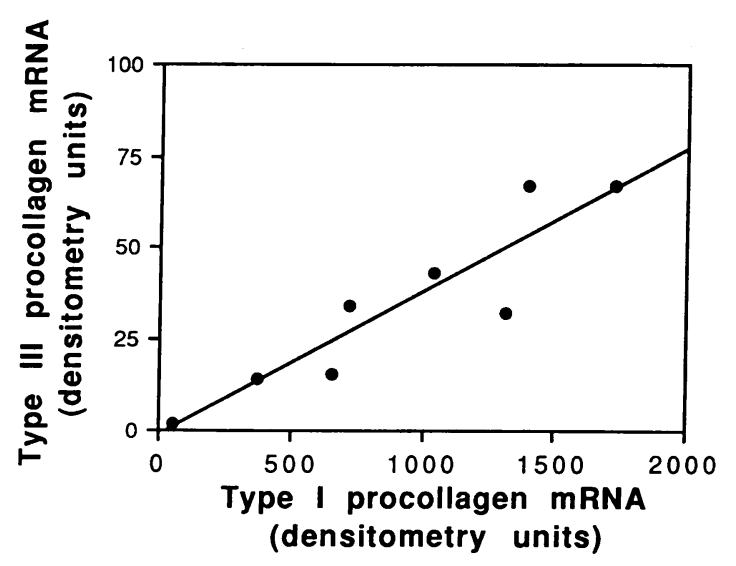

Figure 6. Comparison of the levels of type III [ $\alpha$ 1(III)] to type I $[\alpha 1(\mathrm{I})+\alpha 2(\mathrm{I})]$ procollagen mRNA in substrains from parent culture L.T.F. After extraction cytoplasmic RNA was transferred to nitrocellulose and hybridized with ${ }^{32} \mathrm{P}$-labeled $\alpha(\mathrm{I}), \alpha 2(\mathrm{I})$, or $\alpha 1$ (III) procollagen probes. RNA was quantitated by densitometric scanning of the autoradiographs. Each point represents the values (expressed in densitometry units) for a single substrain. surements of transcription and mRNA stability are required to establish the molecular basis for heterogeneity in matrix synthetic capacity among substrains.

We previously noted variation in the ratios of levels of $\alpha 1$ (I) and $\alpha 2$ (I) procollagen mRNAs in cultured human chondrocytes and synovial fibroblasts $(19,21,22,34)$. These results suggested that the expression of these procollagen genes is not coordinately regulated. We speculated that the excess $\alpha 2(\mathrm{I})$ procollagen mRNA was either not translated or the translated product was not secreted by the cells. Similar variation in the ratio of the levels of the $\alpha 1(\mathrm{I})$ and $\alpha 2$ (I) procollagen mRNAs was observed among the dermal substrains in the present report, consistent with differential regulation of these two procollagen mRNAs. Furthermore, the results would indicate that the normal ratio of $\alpha 1(\mathrm{I}) / \alpha 2$ (I) of $2: 1$ in parent cultures may reflect the average of constituent populations that vary significantly from this ratio.

Miskulin et al. (25) previously reported that the expression of the type III collagen gene is modulated coordinately with that of the type I collagen genes based on comparison of procollagen mRNA levels in dividing and nondividing cells. In our studies we did not observe a correlation between collagen synthesis and cell doubling times. However, the levels of type III procollagen mRNA were strongly correlated with those of type I $(r=0.86 ; P<0.001)$. This correlation was best between $\alpha 1$ (III) and $\alpha 2$ (I) $(r=0.89 ; P<0.001)$ compared with that between $\alpha 1$ (III) and $\alpha 1$ (I) $(r=0.79 ; P<0.01)$. Our results are consistent with coordinate regulation of types I and III collagen gene expression in these substrain populations.

Botstein et al. (7) have reported that there is marked heterogeneity in the capacity of cloned human foreskin fibroblasts to incorporate $\left[{ }^{3} \mathrm{H}\right]$ proline into collagens, although the specific collagen types synthesized were not characterized. More recently, Crouch et al. (35) have reported that morphologically distinct clones of a human tumor cell line exhibit heterogeneity in the production of collagen as well as fibronectin. Dermal fibroblasts cultured from patients with scleroderma produce more types I and III collagen than fibroblasts from normal subjects (36-38); this enhanced collagen synthesis is accompanied by increased steady-state levels of types I and III procollagen mRNAs. Since the scleroderma phenotype persists over many passages in vitro these observations are consistent with the selection of populations of fibroblasts in vivo which are characterized by high rates of collagen synthesis. Our findings of heterogeneity in the pattern of matrix synthesis among substrains derived from normal dermal fibroblasts provide a rationale for apparent clonal selection of fibroblasts in a disease such as scleroderma. Of interest in this regard are our earlier observations that short-term exposure of dermal cell cultures to mononuclear cell conditioned medium results in selection of cell populations with enhanced proliferative and $\mathrm{PGE}_{2}$-synthetic responses upon reexposure to this mononuclear cell conditioned medium (1). In analogous studies, Duncan and Berman have shown that transient exposure of dermal fibroblasts to $\gamma$-interferon leads to a persistent decrease in collagen synthesis (39). Inflammatory cytokines may thus have longlasting effects on the phenotype of connective tissue cells.

In this report we have also described responses of fibroblast substrains to two hormones that affect connective tissue remodeling. Since $\mathrm{PGE}_{2}$ has been shown to modulate collagen synthesis by autocrine as well as paracrine mechanisms, we were particularly interested in establishing whether or not 
there was a correlation between $\mathrm{PGE}_{2}$ responsiveness and the level of collagen synthesis $(22,34,40)$. We had previously shown that the responsiveness of many different connective tissue cell types (including dermal-, synovial-, and bone-derived cells) to $\mathrm{PGE}_{2}$ is markedly influenced by the levels of endogenous $\mathrm{PGE}_{2}(28-30)$. Treatment of cultured cells with mononuclear cell products such as IL-1 $\beta$ or tumor necrosis factor- $\alpha$, which increased endogenous $\mathrm{PGE}_{2}$ synthesis, resulted in desensitization to $\mathrm{PGE}_{2}$ stimulation. These results were consistent with downregulation of receptors by high ambient levels of $\mathrm{PGE}_{2}$. In the present studies we did not observe a correlation between endogenous levels of $\mathrm{PGE}_{2}$ production and $\mathrm{PGE}_{2}$-induced cAMP responses. Basal unstimulated levels of $\mathrm{PGE}_{2}$ were very low $(1.6-7.5 \mathrm{ng} / \mathrm{ml})$ in medium from these cells, however, and based on previous studies with skin and synovial fibroblasts $(28,29)$ higher levels of $\mathrm{PGE}_{2}$ may be required for receptor downregulation.

We had previously reported that cells cultured from human dermis increase cAMP levels after incubation with PTH $(16,26,27)$. We demonstrated by photoaffinity labeling that the PTH receptor in these cells was similar to that in other PTH target tissues (bone and kidney) (41). Others have confirmed our observations concerning PTH responsiveness in dermal cultures, although the kinetics of PTH binding may differ in skin- and bone-derived cells (42-44). We were interested in examining the cells for responses to PTH, since this hormone may also modulate collagen synthesis (possibly by inducing increases in intracellular cAMP levels) $(45,46)$. Our present results indicate that, similar to $\mathrm{PGE}_{2}$, the substrains exhibit marked heterogeneity in their responsiveness to PTH. In fibroblast substrains obtained from one sample, PTH and $\mathrm{PGE}_{2}$ were positively correlated, but this was not observed in substrains from another sample. These results favor heterogeneity in cell surface receptor function rather than a generalized up- or downregulation of adenylate cyclase activity. We have not examined the substrains for the capacity to produce the recently described PTH-related peptide (47-51). This ligand does increase cAMP levels in PTH-responsive tissues including dermis, and could potentially downregulate $\mathrm{PTH}$ receptors in a manner analogous to endogenous $\mathrm{PGE}_{2}$.

One factor potentially contributing to the heterogeneity in the patterns of collagen synthesis among the substrains could be related to differences in growth rates and the effects of in vitro aging $(5,6)$ on cell phenotype. This would be relevant to the data in Table I, in which the parent (L.T.F.) was PTH responsive and substrains were unresponsive to this hormone. The parent cells had undergone far fewer doublings in comparison to the clones. However, the stability of substrain phenotype with respect to collagen synthesis and $\mathrm{PGE}_{2}$ response found in these studies and in previous investigations (1-3) argues against aging or senescence as the cause of the phenotypic diversity.

In conclusion, our studies demonstrate that connective tissue cell substrains cloned from normal human dermal tissues are heterogeneous both in terms of synthetic products and in the activity of cell surface receptors for hormones that regulate connective tissue cell function. Selective expansion of cell populations of connective tissue cells in vivo could give rise to tissues with aberrent patterns of matrix synthesis. In addition, alterations in responses to hormones that regulate these cells could contribute to the disturbance in normal functional activity. Similar processes may also be involved in connective tissue remodeling under physiologic conditions.

\section{Acknowledgments}

We thank Michele Angelo for preparation of the manuscript.

This work was supported by NIH grants AM-03564, AR-32343, and AR-20621, and grants from the Medical Research Service of the Veterans Administration and the Arthritis Foundation.

This is publication number 1056 of the Robert W. Lovett Memorial Group in the Study of Diseases Causing Deformities.

\section{References}

1. Korn, J. H., D. Torres, and E. Downie. 1983. Fibroblast prostaglandin $E_{2}$ synthesis. Persistence of an abnormal phenotype after short-term exposure to mononuclear cell products. J. Clin. Invest. 71:1240-1246.

2. Korn, J. H., D. Torres, and E. Downie. 1984. Clonal heterogeneity in the fibroblast response to mononuclear cell derived mediators. Arthritis Rheum. 27:174-179.

3. Korn, J. H., C. E. Brinckerhoff, and R. L. Edwards. 1985. Synthesis of $\mathrm{PGE}_{2}$, collagenase and tissue factor by fibroblast substrains: substrains are differentially activated for different metabolic products. Collagen Relat. Res. 5:437-447.

4. Korn, J. H. 1985. Substrain heterogeneity in prostaglandin $E_{2}$ synthesis of human dermal fibroblasts: differences in prostaglandin $E_{2}$ synthetic capacity of substrains are not stimulus-restricted. Arthritis Rheum. 28:315-322.

5. Smith, J. R., and L. Hayflick. 1974. Variation in the life-span of clones derived from human diploid cell strains. J. Cell Biol. 62:48-53.

6. Martin, G. M., C. A. Sprague, T. H. Norwood, and W. R. Pendergrass. 1974. Clonal selection, attenuation and differentiation in an in vitro model of hyperplasia. Am. J. Pathol. 74:137-154.

7. Botstein, G. R., G. K. Sherer, and E. C. LeRoy. 1982. Fibroblast selection in scleroderma: an alternative model of fibrosis. Arthritis Rheum. 25:189-195.

8. Ko, S. D., R. C. Page, and A. S. Narayanan. 1977. Fibroblast heterogeneity and prostaglandin regulation of subpopulations. Proc. Natl. Acad. Sci. USA. 74:3429-3432.

9. Brinckeroff, C. E., and J. E. Nagel. 1981. Collagenase production by cloned populations of rabbit synovial fibroblasts. Collagen Relat. Res. 1:433-444.

10. Benditt, E. P., and J. M. Benditt. 1973. Evidence for a monoclonal origin of human atherosclerotic plaques. Proc. Natl. Acad. Sci. USA. 70:1753-1756.

11. Hassell, T. M., R. C. Page, A. S. Narayanan, and C. G. Cooper. 1976. Diphenylhydantoin (Dilantin) gingival hyperplasia: drug-induced abnormality of connective tissue. Proc. Natl. Acad. Sci. USA. 73:2909-2912.

12. Liotta, L. A. 1986. Tumor invasion and metastases-role of the extracellular matrix: Rhoads Memorial Award Lecture. Cancer Res. 46:1-7.

13. Liotta, L. A., C. N. Rao, and S. H. Barsky. 1983. Tumor invasion and the extracellular matrix. Lab. Invest. 49:636-649.

14. Whiteside, T. L., M. Ferrarini, P. Hebda, and R. B. Buckingham. 1988. Heterogeneous synthetic phenotype of cloned scleroderma fibroblasts may be due to aberrant regulation in the synthesis of connective tissues. Arthritis Rheum. 31:1221-1229.

15. Pearson, T. A., J. M. Dillman, K. Solez, and R. H. Heptinstall. 1978. Clonal markers in the study of the origin and growth of human atherosclerotic lesions. Circ. Res. 43:10-18.

16. Goldring, S. R., J.-M. Dayer, R. G. G. Russell, H. J. Mankin, and S. M. Krane. 1978. Response to hormones of cells cultured from human giant cell tumors of bone. J. Clin. Endocrinol. Metab. 46:425433.

17. Goldring, S. R., M. S. Roelke, K. K. Petrison, and A. K. Bhan. 1987. Human giant cell tumors of bone. Identification and characterization of cell types. J. Clin. Invest. 79:483-491.

18. Amento, E. P., A. K. Bhan, K. G. McCullagh, and S. M. Krane. 1985. Influences of gamma interferon on synovial fibroblast-like cells. Ia induction and inhibition of collagen synthesis. J. Clin. Invest. 76:837-848. 
19. Stephenson, M. L., S. M. Krane, E. P. Amento, P. A. McCroskery, and $M$. Byrne. 1985. Immune interferon inhibits collagen synthesis by rheumatoid synovial cells associated with decreased levels of the procollagen mRNAs. FEBS (Fed. Eur. Biochem. Soc.) Lett. 180:4350.

20. White, B. A., and F. C. Bancroft. 1982. Cytoplasmic dot hybridization: simple analysis of relative mRNA levels in multiple small cell or tissue samples. J. Biol. Chem. 257:8569-8572.

21. Goldring, M. B., L. J. Sandell, M. L. Stephenson, and S. M. Krane. 1986. Immune interferon suppresses levels of procollagen mRNA and type II collagen synthesis in cultured human articular and costal chondrocytes. J. Biol. Chem. 261:9049-9056.

22. Goldring, M. B., and S. M. Krane. 1987. Modulation by recombinant interleukin 1 of synthesis of types I and III collagens and associated procollagen mRNA levels in cultured human cells. J. Cell. Biol. 262:16724-16729.

23. Chu, M.-L., J. C. Myers, M. P. Bernard, J.-F. Ding, and F. Ramirez. 1982. Cloning and characterization of five overlapping cDNA's specific for the human pro $\alpha$ l(I) collagen chain. Nucleic Acids Res. 10:5925-5934.

24. Bernard, M. P., J. C. Myers, M.-L. Chu, F. Ramirez, E. F. Eikenberry, and D. J. Prockop. 1983. Structure of a cDNA for the pro 22 chain of human type I procollagen: comparison with chick cDNA for pro $\alpha 2(I)$ identifies structurally conserved features of the protein and the gene. Biochemistry. 22:1139-1145.

25. Miskulin, M., R. Dalgleish, B. Kluve-Beckerman, S. I. Rennard, P. Tolstoshev, M. Brantly, and R. G. Crystal. 1986. Human type III collagen gene expression is coordinately modulated with the type I collagen genes during fibroblast growth. Biochemistry. 25:1408-1413.

26. Goldring, S. R., J. E. Mahaffey, M. Rosenblatt, J.-M. Dayer, J. T. Potts, Jr., and S. M. Krane. 1979. Parathyroid hormone inhibitors: comparison of biological activity in bone- and skin-derived tissue. J. Clin. Endocrinol. Metab. 48:655-659.

27. Goldring, S. R., M. S. Roelke, F. R. Bringhurst, and M. Rosenblatt. 1985. Differential effects of parathyroid hormone responsive cultured human cells on the biological activity of parathyroid hormone and parathyroid hormone inhibitory analogues. Biochemistry. 24:513-518.

28. Goldring, S. R., J.-M. Dayer, and S. M. Krane. 1984. Rheumatoid synovial cell hormone responses modulated by cell-cell interactions. Inflammation. 8:107-121.

29. Dayer, J.-M., S. R. Goldring, D. R. Robinson, and S. M. Krane. 1979. Effects of human mononuclear cell factor on cultured rheumatoid synovial cells: interactions of prostaglandin $E_{2}$ and cyclic adenosine 3',5'-monophosphate. Biochim. Biophys. Acta. 586:87-105.

30. Goldring, S. R., M. S. Roelke, K. K. Petrison, A. E. Evins, and S. M. Krane. 1987. Mechanisms by which monocyte-macrophage products regulate responses of connective tissue (bone and synovial) cells to hormones. J. Bone Miner. Res. 2:239. (Abstr.)

31. Bitterman, P. B., M. D. Wewers, S. I. Rennard, S. Adelberg, and R. G. Crystal. 1986. Modulation of alveolar macrophage-driven fibroblast proliferation by alternative macrophage mediators. J. Clin. Invest. 77:700-708.

32. Wyler, D. J., S. Prakash, and P. Libby. 1987. Mesenchymal target cell specificity of egg granuloma-derived fibroblast growth factor in schistosomiasis. J. Infect. Dis. 155:728-736.

33. Cotran, R. S. 1978. Monocytes, proliferation and glomerulonephritis. J. Lab. Clin. Med. 92:837-840.

34. Goldring, M. B., J. Birkhead, L. J. Sandell, T. Kimura, and S. M. Krane. 1988. Interleukin 1 suppresses expression of cartilagespecific types II and IX collagens and increases types I and III collagens in human chondrocytes. J. Clin. Invest. 82:2026-2037.

35. Crouch, E. C., K. R. Stone, M. Bloch, and R. W. McDivitt. 1987. Heterogeneity in the production of collagens and fibronectin by morphologically distinct clones of a human tumor cell line: evidence for intratumoral diversity in matrix protein biosynthesis. Cancer Res. 47:6086-6092.
36. Uitto, J., E. A. Bauer, and A. Z. Eisen. 1979. Scleroderma. Increased biosynthesis of triple-helical type I and type III procollagens associated with unaltered expression of collagenase by skin fibroblasts in culture. J. Clin. Invest. 64:921-930.

37. Graves, P. N., I. K. Weiss, J. S. Perlish, and R. Fleischmajer. 1983. Increased procollagen mRNA levels in scleroderma skin fibroblasts. J. Invest. Dermatol. 80:130-132.

38. Kahari, V. M., T. Vuorio, and K. Nasto-Salonen. 1984. Increased type I collagen mRNA levels in cultured scleroderma fibroblasts. Biochim. Biophys. Acta. 781:183-186.

39. Duncan, M. R., and B. Berman. 1987. Persistence of a reduced-collagen-producing phenotype in cultured scleroderma fibroblasts after short-term exposure to interferons. J. Clin. Invest. 79:1318-1324.

40. Krane, S. M., J.-M. Dayer, L. S. Simon, and M. S. Byrne. 1985. Mononuclear cell-conditioned medium containing mononuclear cell factor (MCF), homologous with interleukin 1, stimulates collagen and fibronectin synthesis by adherent rheumatoid synovial cells: effects of prostaglandin $\mathrm{E}_{2}$ and indomethacin. Collagen Relat. Res. 5:99-117.

41. Goldring, S. R., G. A. Tyler, S. M. Krane, J. T. Potts, Jr., and M. Rosenblatt. 1984. Photoaffinity labeling of parathyroid hormone receptors: comparison of receptors across species and target tissues and after desensitization to hormone. Biochemistry. 23:498-502.

42. Pun, K. K., C. D. Arnaud, and R. A. Nissenson. 1988. Parathyroid hormone receptors in human dermal fibroblasts: structural and functional characterization. J. Bone Miner. Res. 3:453-460.

43. Silve, C., A. Santora, N. Breslau, A. Moses, and A. Spiegel. 1986. Selective resistance to parathyroid hormone in cultured skin fibroblasts from patients with pseudo-hypoparathyroidism type $1 \mathrm{~b} . J$. Clin. Endocrinol. Metab. 62:640-644.

44. Silve, C., A. Santora, and A. Spiegel. 1985. A factor produced by cultured rat leydig tumor (Rice-500) cells associated with humoral hypercalcemia stimulates adenosine $3^{\prime}: 5$ '-monophosphate production via the parathyroid hormone receptor in human skin fibroblasts. $J$. Clin. Endocrinol. Metab. 60:1144-1147.

45. Kream, B. E., D. W. Rowe, S. C. Cwarek, and L. G. Raisz. 1980. Parathyroid hormone alters collagen synthesis and procollagen mRNA levels in fetal rat calvaria. Proc. Natl. Acad. Sci. USA. 77:5654-5658.

46. Berg, R. A., J. Moss, B. J. Baum, and R. G. Crystal. 1981. Regulation of collagen production by $\beta$-adrenergic system. J. Clin. Invest. 67:1457-1462.

47. Suva, L. J., G. A. Winslow, R. E. H. Wettenhall, R. G. Hammonds, J. M. Moseley, H. Diefenbach-Jagger, C. P. Rodda, B. E. Kemp, H. Rodrigues, E. Y. Chen, P. J. Hudson, T. J. Martin, and W. I. Wood. 1987. A parathyroid hormone-related protein implicated in malignant hypercalcemia: cloning and expression. Science (Wash. DC). 237:893-895.

48. Strewler, G. J., P. H. Stern, J. W. Jacobs, J. Eveloff, R. F. Klein, S. C. Leung, M. Rosenblatt, and R. A. Nissenson. 1987. Parathyroid hormonelike protein from human renal carcinoma cells. J. Clin. In vest. 80:1803-1807.

49. Stewart, A. F., T. Wu, D. Goumas, W. J. Burtis, and A. E. Broadus. 1987. N-terminal amino acid sequence of two novel tumorderived adenylate cyclase-stimulating proteins: identification of parathyroid hormone-like and parathyroid hormone-unlike domains. Biochem. Biophys. Res. Commun. 146:672-678.

50. Nissenson, R. A., D. Diep, and G. J. Strewler. 1988. Synthetic peptides comprising the amino-terminal sequence of a parathyroid hormone-like protein from human malignancies: binding to parathyroid hormone receptors and activation of adenylate cyclase in bone cells and kidney. J. Biol. Chem. 263:12866-12871.

51. Danks, J. A., P. R. Ebeling, J. Hayman, S. T. Chou, J. M. Moseley, J. Dunlop, B. E. Kemp, and T. J. Martin. 1989. Parathyroid hormone-related protein: immunohistochemical localization in cancers and in normal skin. J. Bone Miner. Res. 4:273-278. 